CZASOPISMO INŻYNIERII LA¿OWEJ, ŚRODOWISKA I ARCHITEKTURY JOURNAL OF CIVIL ENGINEERING, ENVIRONMENT AND ARCHITECTURE

JCEEA, t. XXXIV, z. 64 (3/II/17), lipiec-wrzesień 2017, s. 443-453, DOI:10.7862/rb.2017.185

Krystyna WRÓBEL ${ }^{1}$

\title{
RESTAURACJA ELEWACJI LETNIEGO PAŁACU LUBOMIRSKICH W RZESZOWIE
}

\begin{abstract}
Letni Pałac Lubomirskich wzniesiony pod koniec XVII przez Hieronima Augustyna Lubomirskiego jako część dużego kompleksu ogrodowego wokół Zamku Lubomirskich jest jednym z najcenniejszych zabytków architektury niesakralnej Rzeszowa. Czasy jego świetności przypadają na połowę XVIII wieku. Wówczas to, wraz z otaczającym go parkiem został rozbudowany i stał się chętnie odwiedzaną rezydencją. Pałac zmieniał właścicieli, a w roku 1908 został sprzedany rodzinie Nieciów, którą w latach 70-tych XX wieku wywłaszczono. W roku 2012 po latach walki Nieciowie odzyskali obiekt, a następnie sprzedali go Okręgowej Izbie Lekarskiej w Rzeszowie. Od roku 2014 Pałac wraz z otoczeniem jest remontowany z przeznaczeniem na siedzibę Izby. W pierwszej kolejności wyremontowano wnętrza, następnie ogrodzenie i elewacje. Na najbliższy okres zaplanowano remont tarasów, odtworzenie ogrodu oraz budowę drogi wewnętrznej i parkingu. Przedmiotem niniejszego artykułu jest przedstawienie zakresu i sposobu remontu elewacji obiektu. Remont elewacji wraz z detalami wystroju przeprowadzono w roku 2016 na podstawie szczegółowej technologii remontu opracowanej przez autorkę artykułu (dostosowanej do stanu technicznego obiektu) oraz programu prac konserwatorskich. Prace były prowadzone pod ścisłym nadzorem Wojewódzkiego Urzędu Ochrony Zabytków. W referacie opisano stan techniczny elewacji przed remontem, zakres prac przygotowawczych, remontowych, napotkane problemy i efekt końcowy - perfekcyjnie odrestaurowane elewacje ze wszystkimi detalami wystroju. Dzięki ogromnemu zaangażowaniu Właściciela obiektu i nakładowi pracy wielu specjalistów możliwe było przywrócenie stanu technicznego i wyglądu elewacji Pałacu z czasów jego świetności.
\end{abstract}

Słowa kluczowe: zabytek architektury niesakralnej, technologia remontu, program prac konserwatorskich

\footnotetext{
${ }^{1}$ Krystyna Wróbel, Politechnika Rzeszowska, Katedra Konstrukcji Budowlanych, ul. Saletyńska 7, 35-083 Rzeszów; tel.: 17 8542974; e-mail: wrobel@ prz.edu.pl
} 


\section{Historia Letniego Pałacu Lubomirskich}

\subsection{Budowa i rozbudowa - czasy świetności}

Letni Pałac Lubomirskich w Rzeszowie został wybudowany pod koniec XVII wieku na podstawie projektu Tylmana z Gameren, w stylu barokowym przez Hieronima Augustyna Lubomirskiego [1, 2]. Pałac powstał w pobliżu Zamku Lubomirskich, na terenie dawnej winnicy, której właścicielem był Mikołaj Spytko Ligęza. Pałac wybudowano z założeniem, że będzie on częścią dużego kompleksu ogrodowego wokół zamku.

W połowie XVIII wieku Jerzy Lubomirski rozbudował Pałac wraz z otaczającym parkiem na podstawie planów Karola Widemanna. Był on w tamtych czasach modną letnią rezydencją - miejscem "mieszkania dla przyjemności".

\subsection{Dalsze losy pałacu}

Pod koniec XVIII wieku pałac wraz z ogrodem zaczął popadać w ruinę. Franciszek Lubomirski jako ostatni właściciel z rodu Lubomirskich sprzedał Pałac Letni wraz z otoczeniem w 1798 r. rodzinie Kostheinów. Pozostałą część ogrodu wraz z zamkiem sprzedano rządowi austriackiemu. Pałac został przebudowany po pożarze, który wg różnych źródeł miał miejsce w 1904, bądź w 1906 roku. Rodzina Kostheinów sprzedała Pałac rodzinie Nieciów w roku 1908. W roku 1968 zespół pałacowy został wpisany do rejestru zabytków pod numerem A-292 i jest objęty ścisłą ochroną konserwatorską. Nieciowie zamieszkiwali i użytkowali Pałac do lat 70-tych XX wieku, tj. do czasu wywłaszczenia ich. Po remoncie przeprowadzonym w 1981 roku Pałac użytkowało Miasto. Rodzina Nieciów po wielu latach, w roku 2012 odzyskała swoją własność, po czym sprzedała Okręgowej Izbie Lekarskiej w Rzeszowie na jej siedzibę. Do chwili obecnej Pałac jest sukcesywnie remontowany na podstawie wykonanych opracowań, m.in. w postaci projektów, ekspertyz, szczegółowych technologii napraw konkretnych elementów i programów prac konserwatorskich [4, 5, 6, 7].

\section{Opis ogólny budynku}

Pałac został wzniesiony w stylu barokowym jako murowany z cegły pełnej na fundamentach kamiennych i częściowo z cegły pełnej. Jest to budynek ukształtowany w rzucie na planie litery "H", symetryczny względem dwóch prostopadłych do siebie osi, całkowicie podpiwniczony. W części środkowej trzykondygnacyjny, skrzydła boczne dwukondygnacyjne $\mathrm{z}$ trzecią kondygnacją $\mathrm{w}$ dachu mansardowym z lukarnami. Część środkowa przykryta dachem dwuspadowym. Pokrycie dachowe, wszystkie obróbki blacharskie, rynny i rury spustowe wykonano z blachy miedzianej. 


\section{Opis elewacji Pałacu}

Widok ogólny elewacji frontowej przed remontem przedstawia rys. 1. Wszystkie elewacje są otynkowane tynkiem wapiennym. Cokół oddzielono od wyższej części elewacji gzymsem betonowym. Elewacje podzielone są boniowanymi lizenami i posiadają bogate zdobienia w postaci:

- elementów rzeźbiarskich - dwóch kamiennych barokowych portali wejściowych - w osi elewacji wschodniej, nad wejściem głównym bogato zdobiony z herbem rodu Lubomirskich i w osi elewacji zachodniej skromniejszy,

- drewnianych kartuszy ozdobionych bogato rzeźbionymi ornamentami,

- ryzalitów bocznych dwukondygnacyjnych; dłuższe boki ryzalitów zwieńczone są trójkątnymi przyczółkami,

- sześciu owalnych nisz z bogatymi obramieniami drewnianymi i umieszczonymi w nich rzeźbionymi w kamieniu popiersiami filozofów,

- drewnianych obramień okien pierwszej i drugiej kondygnacji,

- gzymsów ozdobnych w poziomie stropu nad drugą kondygnacją,

- gzymsów pod parapetami okien.

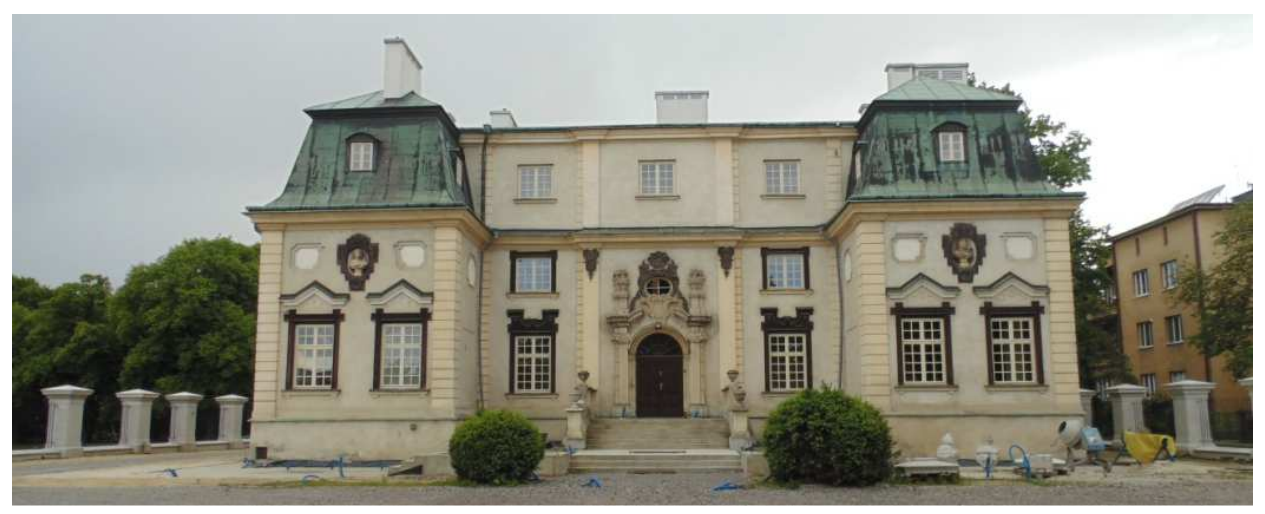

Rys. 1. Widok elewacji frontowej (wschodniej) przed remontem

Fig. 1. View of the main (east) façade before renovation

\section{Opis stanu technicznego elewacji i detali architektonicznych}

Stan elewacji oceniono na podstawie obserwacji i badań własnych $[5,6]$ oraz posiłkując się opracowaniem [7]. Ostatni remont elewacji przeprowadzono około 35 lat temu i był to remont dość powierzchowny. 


\subsection{Elewacje}

Elewacje były zakurzone, zabrudzone i zniszczone. Na cokole całego budynku stwierdzono zacieki i wykwity solne świadczące o kapilarnym podciąganiu wód gruntowych. Gzyms nad cokołem wykonany z prefabrykatów betonowych lokalnie spękany, z ubytkami i nieszczelnościami. W wielu miejscach na elewacji tynk był odparzony i odspajał się. Stwierdzono liczne spękania elewacji rozwijające się od naroży otworów okiennych oraz liczne zacieki świadczące o nieszczelności i zużyciu technicznym obróbek blacharskich (rys. 2, 4). Całe połacie elewacji pokryte były siatką rys skurczowych świadczących o niewłaściwym doborze składu zaprawy tynkarskiej i/lub złej pielęgnacji świeżych tynków. Rynny i rury spustowe lokalnie nieszczelne i zdeformowane, a lokalnie ich brakowało. $\mathrm{W}$ obszarach elewacji zalewanych wodami pochodzącymi z nieszczelnych rur

Rys. 2. Pęknięcia na styku schody - zasadnicza bryła budynku, zacieki $\rightarrow$

Fig. 2. Cracks at the junction of the stairs building block, streaks $\rightarrow$

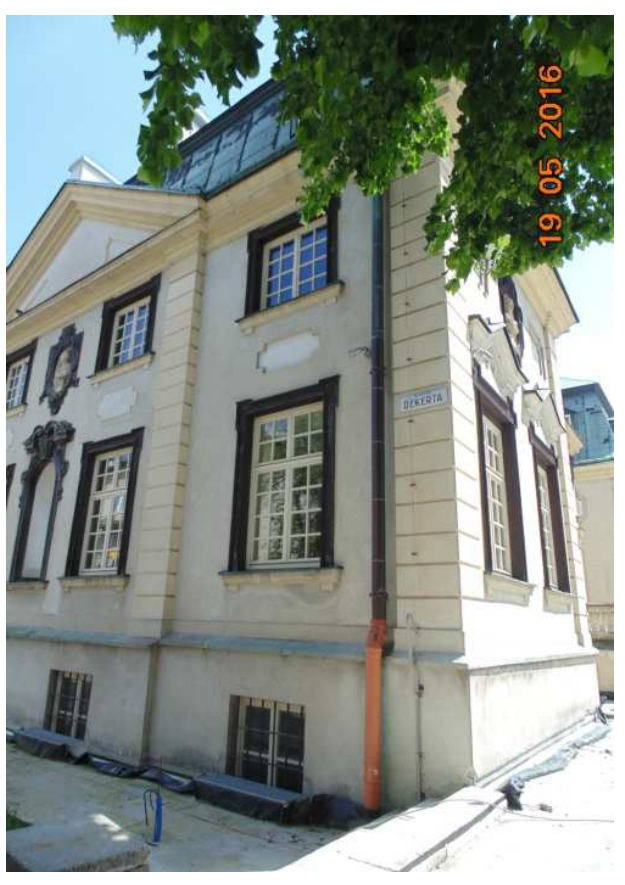

Rys. 3. Narożnik północno-wschodni budynku - zacieki, uszkodzenia

Fig. 3. North-eastern corner of the building stain, defects

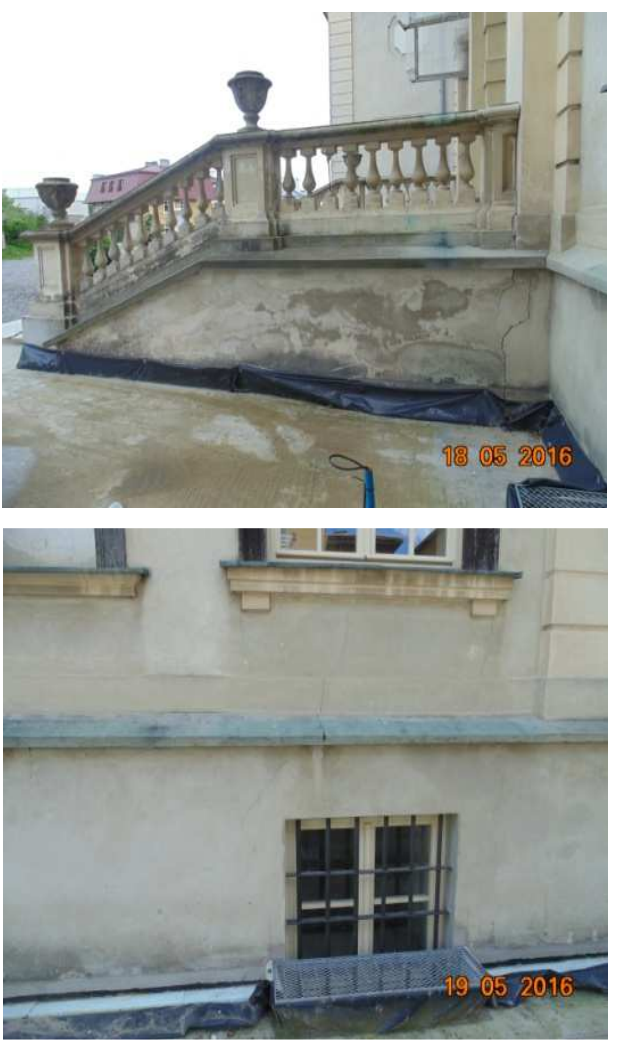

Rys. 4. Jak obok, zbliżenie uszkodzeń

Fig. 4. As the next, enlargement of defects 
spustowych oraz $\mathrm{w}$ miejscu ich braku nastąpiła przyśpieszona degradacja materiału ścian. Elewacje były zanieczyszczone odchodami ptasimi gniazdujących w niszach gołębi (rys. 5).

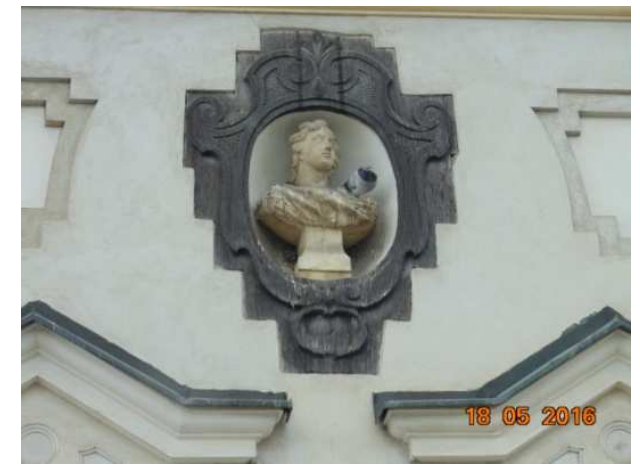

Rys. 5. Uszkodzenia i zanieczyszczenia obramienia niszy z popiersiem

Fig. 5. Damage and contamination of the niche with a bust framing

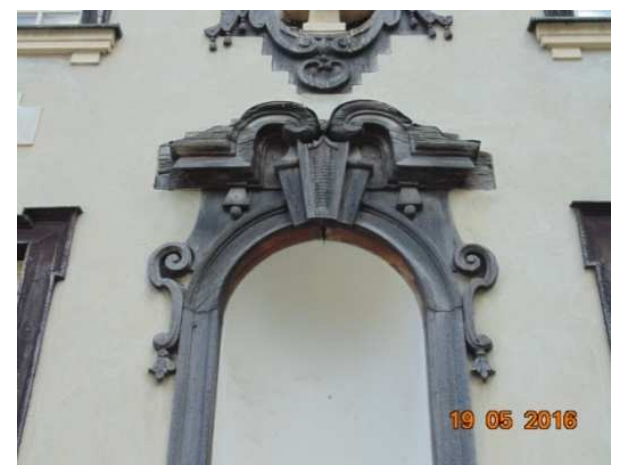

Rys. 6. Uszkodzenia i zanieczyszczenia obramienia dużej niszy

Fig. 6. Damage and contamination of the large niche framing

\subsection{Detale architektoniczne}

Elewacja wschodnia jest elewacją o najbogatszych zdobieniach w postaci elementów rzeźbiarskich wykonanych $\mathrm{z}$ drewna oraz kamienia naturalnego i sztucznego. Drewniane obramienia okienne oraz kartusze pod gzymsem w części środkowej - stan techniczny bardzo zły. W wyniku oddziaływania czynników atmosferycznych powstały liczne ubytki drewna, spękania, stwierdzono drobne wstawki nowego drewna pochodzące z ostatniego remontu (rys. 5, 6). Uszkodzenia powierzchniowe i spękania elementów kamiennych bogato zdobionego portalu. Bardzo poważnym problemem było zanieczyszczenie elementów odchodami ptasimi gniazdujących $\mathrm{w}$ niszach z popiersiami gołębi (rys. 5), które nie tylko psują estetykę, ale również stanowią pożywkę dla rozwoju szkodliwych mikroorganizmów niszczących drewno. W lepszym stanie zastano drewniane obramienia okien. Opisane wyżej uszkodzenia na nich występowały, jednak w mniejszym zakresie. Lakiernicza powłoka zabezpieczająca elementy drewniane uległa prawie całkowitemu złuszczeniu.

Na elementach rzeźbionych portalu wejściowego stwierdzono:

- liczne pęknięcia i drobne ubytki, w których w trakcie opadów atmosferycznych gromadzi się woda; woda zamarzając i odmarzając powoduje destrukcję coraz głębszych warstw kamienia (rys. 7, 8),

- nalot tzw. "czarnej patyny", która z uwagi na szkodliwe właściwości fizyko-chemiczne uszkadza powierzchniową warstwę kamienia. 


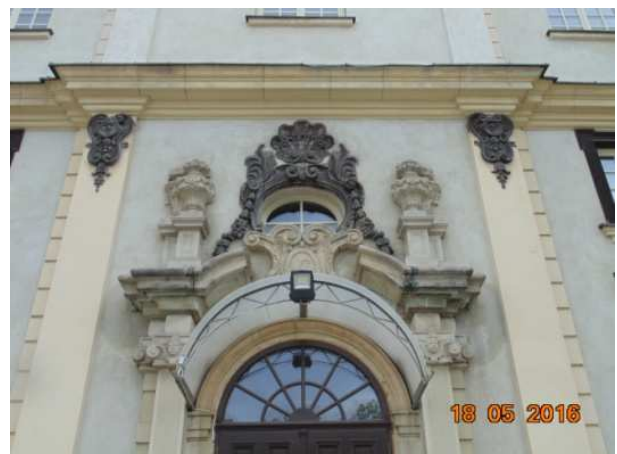

Rys. 7. Widok uszkodzeń portalu wejścia głównego

Fig. 7. View of the main entrance portal damages

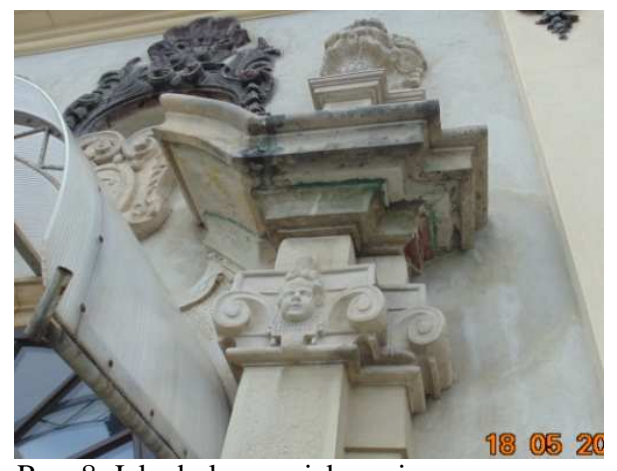

Rys. 8. Jak obok - powiększenie Fig. 8. As next to - enlargement

Estetykę wejścia głównego do budynku dodatkowo psuł współczesny daszek pokryty poliwęglanem (rys. 7.). Pozostałe elewacje - stwierdzono analogiczne uszkodzenia i wady jak na elewacji wschodniej. Uszkodzenia elementów drewnianych elewacji zachodniej (kartuszy i obramień okiennych) są znacznie większe niż na pozostałych elewacjach. Dotyczy to również elementów kamiennych.

\section{Zakres wykonanych prac remontowych i konserwatorskich}

\subsection{Elewacje}

Prace remontowe elewacji wykonano dzieląc je na dwa etapy.

Etap I - remont cokołu budynku w nawiązaniu do wcześniej wykonanego remontu i izolacji ścian piwnic. Przygotowano podłoże poprzez skucie skorodowanego tynku z całej powierzchni z równoczesnym oczyszczeniem spoin na głębokość $2 \mathrm{~cm}$, zmycie powierzchni cokołu strumieniem wody pod ciśnieniem, odgrzybienie jej i uzupełnienie ubytków muru poprzez szpałdowanie. Zszyto rysy i szczeliny w murze (rys. 9-10), kierując się zasadą, polegającą na tym, że rysy mają być zszywane w kierunku prostopadłym do ich przebiegu. Spoiny po usuniętej zaprawie uzupełniono tynkiem renowacyjnym. Wykonano izolację mineralną do wysokości $30 \mathrm{~cm}$ nad terenem (łącząc ją z istniejącą izolacją ścian piwnic), a następnie na całej powierzchni cokołu wykonano tynk renowacyjny. Wyremontowano gzyms betonowy $\mathrm{w}$ poziomie wierzchu cokołu $\mathrm{z}$ odtworzeniem i uszczelnieniem dylatacji uszczelniaczem poliuretanowym.

Etap II - wykonano remont elewacji budynku powyżej cokołu. Zakres prac remontowych obejmował czynności opisane powyżej, a oprócz tego remont i uszczelnienie rynien, rur spustowych i miedzianych obróbek blacharskich elementów wystroju elewacji (rys. 11-15). 


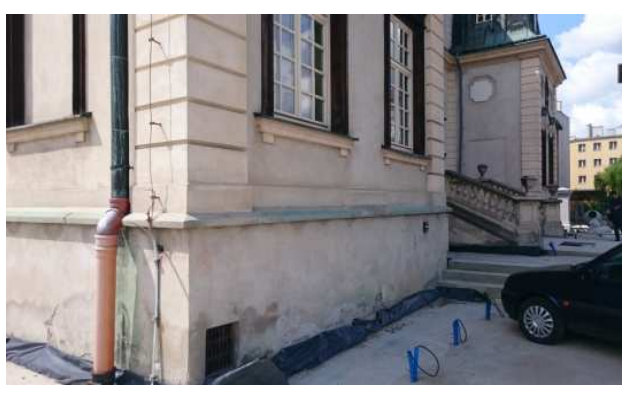

Rys. 9. Widok cokołu Pałacu przed remontem Fig. 9. View of the plinth before the repair

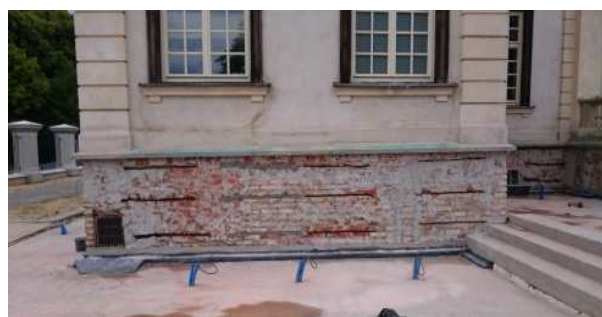

Rys. 10. Widok cokołu w trakcie remontu i zszywania rys

Fig. 10. View of the plinth during the repair and stapling of the cracks

Ostatnim etapem prac było zabezpieczenie elewacji przed wpływem czynników atmosferycznych. Gładkie powierzchnie tynkowane zabezpieczono poprzez hydrofobizacje, natomiast gzymsy, bonie, nisze pomalowano farbami krzemianowymi, zachowując ich wcześniejszą kolorystykę. Prace wykonano bazując głównie na materiałach firm Sika i Ceresit.

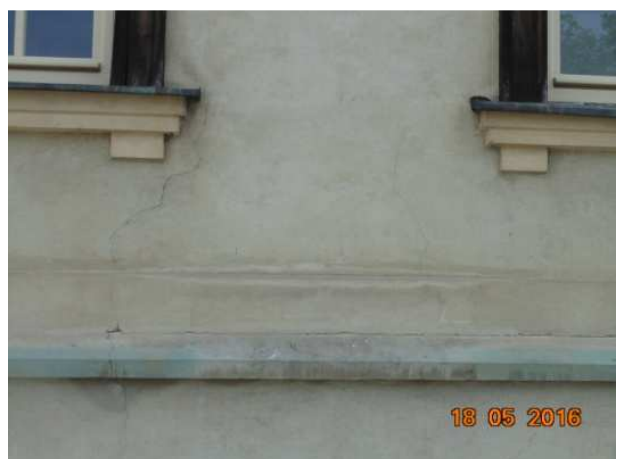

Rys. 11. Zarysowania elewacji zachodniej

Fig. 11. Cracks of the western façade

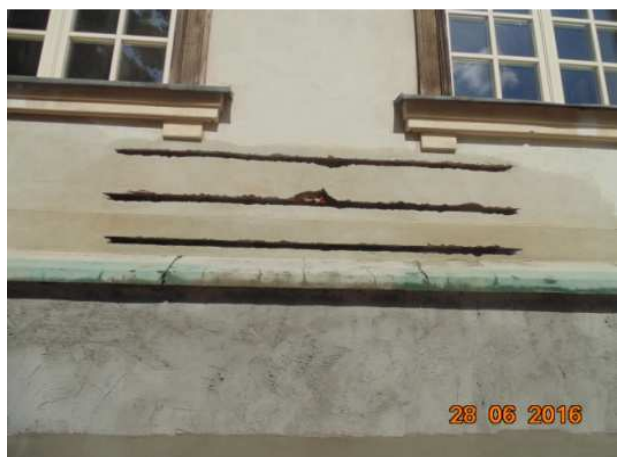

Rys. 12. Przykładowa naprawa rys elewacji Fig. 12. Example of façade cracks repair

\subsection{Detale architektoniczne}

Dla każdego z dwóch rodzajów materiałów użytych do wykonania elementów dekoratorskich elewacji, tj. kamienia i drewna opracowano programy prac konserwatorskich [7] zgodnie z którymi przeprowadzono prace.

Kamień - restauracja i konserwacja detali architektonicznych obejmowała usunięcie przyczyn destrukcji w możliwym zakresie oraz przywrócenie ich formy w miarę możliwości najbardziej zbliżonej do oryginału. Prace rozpoczęto od usunięcia różnego typu zabrudzeń i zanieczyszczeń. Następnie zneutralizowano i usunięto mikroflorę. Częściowo usunięto sole $\mathrm{z}$ elementów kamiennych, po 
czym wykonano wzmocnienie strukturalne kamienia, sztucznego kamienia i zaprawy w miejscach, gdzie stwierdzono uszkodzenia z zastosowaniem preparatu krzemoorganicznego. Ubytki ww. materiałów uzupełniono gotowymi zaprawami przygotowanymi fabrycznie, które kolorem i strukturą naśladują oryginalną powierzchnię oryginału. W miejscach, gdzie ubytki były zbyt duże i ich uzupełnienie wykonywano nowymi ciosami, stosując kamień dobrany do substancji oryginalnej. Uzupełnienia i wymiany najbardziej zniszczonych partii spoiwa wykonano fabrycznie przygotowanymi kitami, dobranymi w taki sposób, aby ich struktura nie różniła się od oryginału.

Drewno - wszystkie elementy objęto takimi samymi rodzajami zabiegów [7], dostosowując ich zakres do stopnia zaawansowania destrukcji. Oczyszczono elementy drewniane $\mathrm{z}$ warstwy zanieczyszczeń oraz mechanicznie usunięto pozostałości powłok malarskich. Zabrudzenia pochodzące $\mathrm{z}$ odchodów ptasich usunięto przeznaczonymi do tego celu detergentami, przeprowadzono dezynfekcję, dezynsekcję i zabieg odszarzania drewna, po czym zaimpregnowano je w obszarach zmurszałych. Ubytki uzupełniono dającymi się obrabiać kitami barwionymi w masie, a następnie zrekonstruowano naprawiane elementy. Zabezpieczono drewno przed szkodliwym oddziaływaniem czynników środowiskowych matowymi lakierobejcami. W pracach konserwatorskich bazowano na materiałach firmy Remmers.

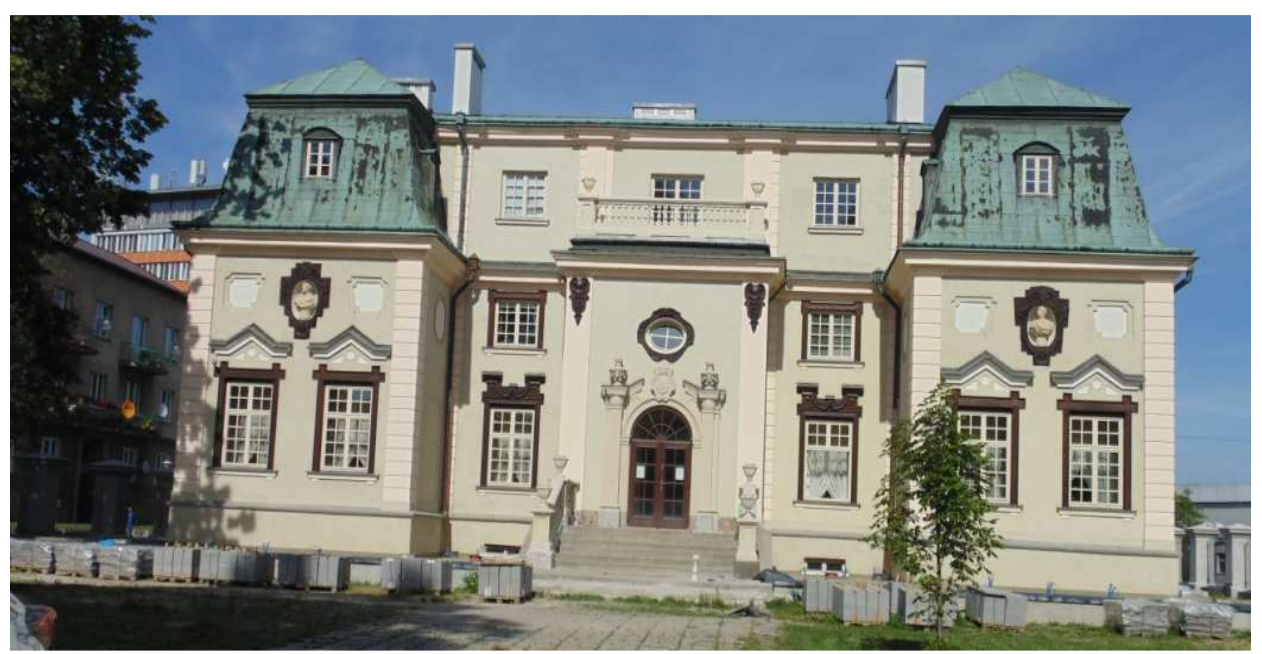

Rys. 13 Widok elewacji zachodniej po remoncie

Fig. 13. View of the west façade after repairs

Po zakończeniu prac remontowych natychmiast okazało się koniecznym zabezpieczenie przed gołębiami nisz elewacji siatkami, a wszelkich elementów wystających kolcami. 

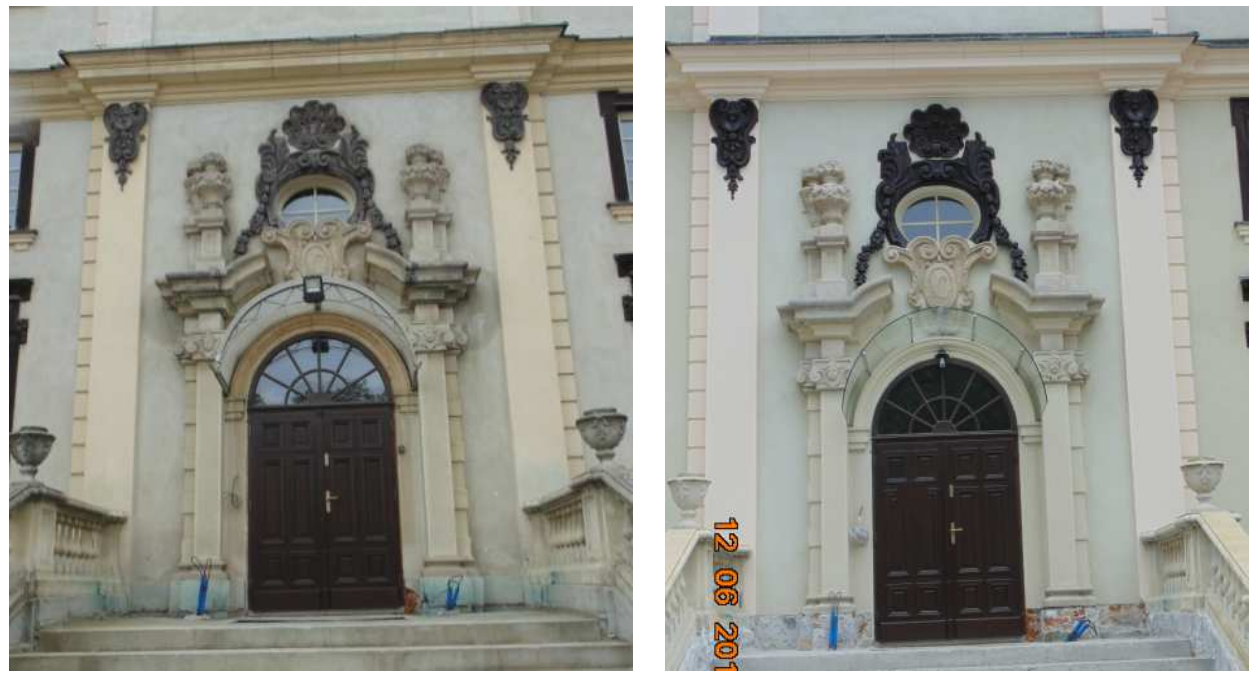

Rys. 14. Portal nad wejściem głównym przed i po renowacji

Fig. 14. Portal over the main entrance before and after the renovation

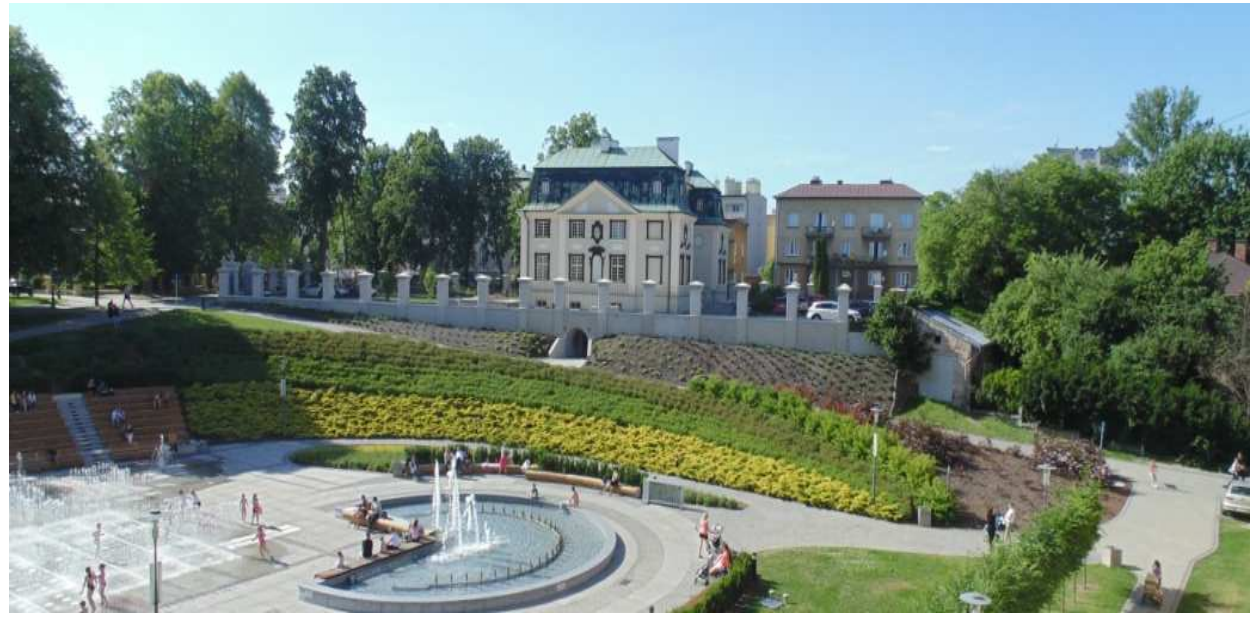

Rys. 15. Widok elewacji południowej i otoczenia po zakończeniu prac

Fig. 15. View of the southern façade and surroundings after finishing work

\section{Podsumowanie}

Wszystkie prace, prowadzono pod ścisłym nadzorem konserwatorskim Wojewódzkiego Urzędu Ochrony Zabytków. Każda decyzja i każdy etap prac poprzedzany był próbami i komisyjnym wyborem najlepszego wariantu. Przy ich 
prowadzeniu kierowano się zasadą zachowania/odtworzenia stanu istniejącego w maksymalnie możliwym zakresie.

Doprowadzenie do stanu prawidłowego wymagało ogromnego nakładu sił i środków, pokonania wielu trudności, zaangażowania wysokiej klasy specjalistów oraz ogromnego wysiłku organizacyjnego. Patrząc na efekt końcowy w postaci wyremontowanych elewacji (rys. 13,15) należy stwierdzić, że wysiłek ten przyniósł oczekiwane efekty.

Restauracja elewacji była jednym z etapów spośród zaplanowanych prac. Na efekt końcowy w postaci kompletnie wyremontowanego pałacu z zagospodarowanym i urządzonym terenem trzeba będzie jeszcze jakiś czas poczekać.

\section{Literatura}

[1] Kotula F.: Tamten Rzeszów, Wydawnictwo LIBRI RESSOVIENSES, Rzeszów 1997.

[2] Karta Ewidencji Zabytku obiektu zabytkowego "Zespół Pałacu Letniego Lubomirskich" wypełniona 31.VIII.1959r. przez T. Żurawską.

[3] http://www.rzeszow.pl/miasto-rzeszow/historia/zabytki-rzeszowa/palac-letni-lubomirskich \{dostęp 09.06.2017 r.\}.

[4] Hałabuz S.: "Projekt budowlany i wykonawczy przebudowy, remontu i zmiany sposobu użytkowania budynku Pałacu Letniego Lubomirskich na budynek administracyjny z mała gastronomią i pokojami gościnnymi dla potrzeb Okręgowej Izby Lekarskiej w Rzeszowie...", Rzeszów, październik 2013 r.

[5] Wróbel K., Kubiszyn W.: Remont zabytkowego ogrodzenia Letniego Pałacu Lubomirskich w Rzeszowie, Czasopismo Inżynierii Lądowej, Środowiska i Architektury Journal of Civil Engineering, Environment and Architecture, JCEEA, t. XXXIII, z. 63 (3/16), czerwiec-lipiec 2016, s.

[6] Wróbel K.: Technologia remontu elewacji Letniego Pałacu Lubomirskich w Rzeszowie przy ul. Dekerta 2, Rzeszów, kwiecień 2016r.

[7] Olszyński J.: Program prac konserwatorskich i restauratorskich Letniego Pałacu Lubomirskich w Rzeszowie przy ul. Dekerta 2. Detale ozdobne elewacji budynku. Przeworsk, maj 2016r.

\section{RESTORATION OF THE FAÇADES OF THE SUMMER LUBOMIRSKI PALACE IN RZESZÓW}

\section{S u m m a r y}

The Lubomirski Summer Palace was erected in the end of the 17th century by Hieronim Augustus Lubomirski as part of a large garden complex around the Lubomirski Castle. It is one of the most valuable not sacred monuments of Rzeszow architecture. Times of his glory fall in the mid18th century, when palace and the surrounding park were expanded and became a readily visited residence. The palace changed owners. In 1908 it was sold to the Nieć family and expropriated in the 70's of the 20th century. After years of battles the family recovered the palace in 2012 and sold it to the Regional Medical Chamber. Since 2014 the palace and its surroundings have been renovated for the seat of the Chamber. First of all the interior of the place was renovated, then the fence and 
façades. For the nearest future following works are planned: renovation of terraces and restoration garden as well as building an internal road and car park. The subject of this article is a detailed presentation of the scope and method of façade renovation of the object. Renovation of the façade with maintenance of decorative details was carried out in 2016 according to the detailed renovation technology developed by the author of this paper (adapted to the technical condition of the facility) and the conservation work program. The work was conducted under the strict supervision of the Provincial Office for the Preservation of Monuments. The paper describes in details the range of preparatory and renovation works, problems encountered during the works and the end result - perfectly restored façades with all details of the architectural decoration. Thanks to the huge involvement of the owner of the facility and the workload of many specialists it was possible to restore the technical condition and appearance of the façades of the palace from its glory times.

Keywords: not sacred monuments, technology of renovation, conservation work program

Przestano do redakcji: 09.06.2017 $r$.

Przyjęto do druku: 01.09.2017 r. 
